\title{
Rebates under EU Competition Law after the 2017 Intel Judgment: The Good, the Bad and the Ugly*
}

\author{
Viktoria H.S.E. Robertson ${ }^{* *}$
}

\begin{abstract}
On 6 September 2017, the Court of Justice of the European Union delivered its long-awaited Intel judgment. The European Commission had accused Intel of inducing customer loyalty and thus foreclosing the relevant market for its competitors through (i) a rebate scheme and (ii) direct payments, both of which the Commission qualified as abuses of dominance under Article 102 TFEU. The General Court upheld the Commission decision in its entirety in June 2014. Before the Grand Chamber of the Court of Justice, however, the General Court's Intel judgment was set aside and the case was referred back to that Court. The Court of Justice held that where the Commission, as in its Intel decision of 2009, also relies on an as-efficient-competitor (AEC) test in order to assess the capability of a rebate scheme to restrict competition contrary to Article 102 TFEU, the General Court must review a party's counterarguments pertaining to this economic analysis. The General Court was instructed to further examine the factual and economic evidence in this respect.

With a view to illuminating the legal questions that posed themselves in Intel, the present contribution reviews the leading European case law on rebate schemes Hoffmann-La Roche, Michelin I and II, British Airways, Tomra and Post Danmark II - as well as the Commission's approach to conditional rebates in its 2009 Guidance Paper. After briefly recalling the different stages of the Intel case, the contribution then offers a commentary on and an analysis of the Court of Justice's Intel judgment and the way in which the Court attempted to reconcile its formalistic case law on rebate schemes with the effects-based economic tests carried out by the Commission.
\end{abstract}

* Date of Reception: 05 January 2018. Date of Acceptance: 13 January 2018.

** Assistant Professor, Institute of Corporate and International Commercial Law, University of Graz, 8010 Graz, Austria; viktoria.robertson@uni-graz.at. I am grateful for insightful comments received from two anonymous reviewers and from participants in my talks at Universidade Católica do Porto in December 2017, in particular Professor Sofia Oliveira Pais, and at Rutgers Law School Camden in January 2018. The usual disclaimer applies. 
KEYWORDS: abuse of dominance, AEC test, as-efficient-competitor test, conditional rebates, exclusivity rebates, Guidance Paper, Intel, loyalty rebates, rebate scheme, rebates

\section{Introduction}

On 6 September 2017, the Court of Justice of the European Union delivered its long-awaited Intel judgment. The European Commission had accused Intel of inducing customer loyalty and thus foreclosing the relevant market for its competitors through (i) a rebate scheme and (ii) direct payments to original equipment manufacturers (OEMs) and a distributor. The Commission qualified both practices as an abuse of dominance under Article 102 TFEU. While the General Court dismissed Intel's appeal of the Commission decision in June 2014, its own judgment was set aside by the Grand Chamber of the Court of Justice and - in an unexpected turn of events - the case was referred back to the General Court. The Court of Justice held that where the Commission, as in its Intel decision of 2009, also relies on an as-efficient-competitor (AEC) test in order to assess the capability of a rebate scheme to restrict competition contrary to Article 102 TFEU, the General Court must review a party's counter-arguments pertaining to this economic analysis. The General Court was instructed to further examine the factual and economic evidence in this respect.

In the following, a short tour d'horizon (section 2) of the European case law on rebate schemes and the European Commission's economic approach to rebates provides the necessary background to discussing the implications of the Intel case (section 3). After recalling the various stages of the case, this contribution focuses on the Court of Justice's recent Intel judgment and the way in which that Court attempted to reconcile its case law on loyalty-inducing rebate schemes with effects-based economic tests relied upon by the Commission. Three insights can be gained from the Court's Intel judgment (section 4): one good, one bad and one ugly. ${ }^{1}$ While the Court's judgment gave some much-needed legal guidance on how to assess the capability of rebate schemes to restrict competition ("the good"), it also left several legal questions on EU competition law's approach to rebate schemes unanswered ("the bad"). Legal uncertainty as

\footnotetext{
${ }^{1}$ These conclusions have nothing in common with Clint Eastwood's blockbuster movie except for their title.
} 
to the legal test for rebate schemes under EU competition law is thus set to be prolonged - for Intel and beyond ("the ugly"). Section 5 closes with some final reflections on rebates after Intel and on the AEC test as a reliable standard in EU competition law.

\section{The competition law assessment of rebates before Intel}

Rebates are an everyday feature of business life. They are generally viewed favourably as they reduce price - one of competition law's central goals. However, under certain circumstances a company with sufficient market power may rely on rebates in order to foreclose competitors from the market, thus harming the process of competition and, in due course, consumer welfare. ${ }^{2}$ Article 102 TFEU prohibits rebates that induce customer loyalty and thereby foreclose competitors, although it remains the issue of intense debate what the legal assessment of loyalty rebates should look like under EU competition law. Observers had pinned high hopes on the Intel case to solve this question. In the following, the leading European case law on rebates is discussed in order to gain a better understanding for the legal questions that were at issue in Intel, with the European Commission's Guidance Paper of 2009 intersected as a possible game changer for future cases. Readers familiar with these cases may wish to directly proceed to section 3.

\subsection{Leading case law predating the Guidance Paper}

From its early years onwards, the Court of Justice of the European Union issued a number of leading judgments on the contentious legal issue of how competition law should deal with rebates by dominant companies. Volume-based quantity rebates have consistently been regarded as permissible under the competition rules, as long as they relate to real cost savings and to individual orders. ${ }^{3}$ Loyalty rebates which are conditioned on

\footnotetext{
${ }^{2}$ On the possible anti-competitive effects of rebates, see Julie Clarke, "The Opinion of AG Wahl in the Intel Rebates case: A triumph of substance over form?”, World Competition: Law \& Economics Review 40, no. 2 (2017): $242 \mathrm{ff}$. On the link between foreclosure and consumer harm, see also European Commission, Guidance on the Commission's enforcement priorities in applying Article 82 of the Treaty to abusive exclusionary conduct by dominant undertakings, 2009 OJ C45/7, paragraph 19.

${ }^{3}$ This is a finding which the Courts have repeated since the late 1970s; see Judgment of 13 February 1979, Hoffmann-La Roche v. Commission, 85/76, EU:C:1979:36, paragraph 90; Judgment of 9 November 1983, Michelin v. Commission (Michelin I), 322/81, EU:C:1983:313, paragraph 72; Judgment of 6 October 2015, Post Danmark v. Konkurrencerådet (Post Danmark II), C23/14, EU:C:2015:651, paragraph 28 (holding that "a simple quantity rebate [should be] linked solely to
} 
exclusive dealing, on the other hand, have traditionally been presumed to constitute an abuse of a dominant position under Article 102 TFEU. To begin with, in the Hoffmann-La Roche case (1979), the Court held that exclusive purchasing obligations as such constitute an infringement of Article 102 TFEU, whether or not they are rewarded with rebates. In a similar vein, fidelity rebates set on an individual basis that do not contain a formal tying arrangement, but require the customer to obtain all or most of its requirements from the dominant undertaking, also constitute an abuse of a dominant position. ${ }^{4}$ The reason for this finding is that these fidelity rebates are both "designed to deprive the purchaser of or restrict his possible choices of sources of supply and to deny other producers access to the market." ${ }^{\prime \prime}$ The Court noted that while fidelity rebates were normally incompatible with the internal market, exceptional circumstances such as those relevant for individual exemption under Article 101(3) TFEU should be taken into account in their assessment. ${ }^{6}$ By this, the Court opened up the possibility of objective justification for fidelity rebates.

In the Michelin I case of 1983, the Court further developed its stance on loyalty rebates as potential abuses of a dominant position. At issue were selective and individual target-based rebates with long reference periods. ${ }^{7}$ The Court held that loyalty rebates ensured that purchasers did not turn to other suppliers for their purchasing requirements, thus constituting an abuse under Article 102 TFEU. ${ }^{8}$ It distinguished the rebates in Michelin I from those in Hoffmann-La Roche, as the former entailed no explicit exclusive purchasing requirement for Michelin's heavy vehicle replacement tyres. ${ }^{9}$ The Court went on to list the circumstances which one had to assess when analysing whether such a rebate scheme was loyalty-inducing and thus abusive within the meaning of Article 102 TFEU, namely the conditions for granting the rebate and whether it is liable to restrict the purchasers' ability to choose their sources of supply or to foreclose competitors' access to the market, whether the rebate scheme applies dissimilar

\footnotetext{
the volume of purchases, [...] granted in respect of each individual order, thus corresponding to the cost savings made by the supplier.").

${ }^{4}$ Judgment of 13 February 1979, Hoffmann-La Roche v. Commission, 85/76, EU:C:1979:36, paragraph 89.

${ }^{5}$ Ibid., paragraph 90.

${ }^{6} \mathrm{Ibid}$.

${ }^{7}$ Judgment of 9 November 1983, Michelin I, 322/81, EU:C:1983:313, paragraphs 81-83.

${ }^{8} \mathrm{Ibid}$., paragraph 71.

${ }^{9} \mathrm{Ibid}$., paragraph 72 .
} 
conditions to equivalent transactions and whether it reinforces the dominant company's market position. ${ }^{10}$

Following these landmark judgments by the Court, the General Court was given several opportunities to weigh in on the antitrust assessment of rebates. In Michelin II (2003), the General Court found that loyalty rebates, through their exclusivity-enhancing nature, can lead to a foreclosure effect and therefore infringe Article 102 TFEU. ${ }^{11}$ The rebates granted by Michelin in that case were quantity rebates which the Commission considered to have a loyalty-inducing effect. ${ }^{12}$ One of Michelin's lines of defence was to argue that its rebate system did not have such a foreclosure effect in practice, and that the Commission should have analysed the actual economic effect of its rebates on the market. ${ }^{13}$ The General Court did not side with Michelin on this question, finding that effect under Article 102 TFEU was not to be understood as actual effect, but rather as conduct that "tends to restrict competition or [...] is capable of having that effect." ${ }^{14}$ It then held that under Article 102 TFEU, object and effect are one and the same, and that conduct which had the object of limiting competition was also liable to have such an effect. ${ }^{15}$ As Michelin's discount system was designed to tie the purchasers to it and this "tended to restrict competition", the Commission had proven anti-competitive effect to the required legal standard. ${ }^{16}$

The General Court was again called upon to determine the compatibility of a rebate scheme with Article 102 TFEU in British Airways (2003). In that case, British Airways had offered rewards for reaching sales targets to travel agents, and its system included retroactive rebates with long reference periods. ${ }^{17}$ The General Court showed an inclination to also assess whether those schemes actually induced customer loyalty, and, if so, whether there was an objective justification for them. ${ }^{18}$ However, at a later stage the General Court returned to its familiar formalistic approach,

\footnotetext{
${ }^{10}$ Ibid., paragraph 73 .

${ }^{11}$ Judgment of 30 September 2003, Michelin v. Commission (Michelin II), T-203/01, EU:T:2003:250, paragraphs 57, 65.

${ }^{12}$ Ibid., paragraph 64.

${ }^{13}$ Ibid., paragraphs $235 \mathrm{ff}$.

${ }^{14}$ Ibid., paragraph 239.

${ }^{15}$ Ibid., paragraph 241.

${ }^{16}$ Ibid., paragraph 244.

${ }^{17}$ Judgment of 17 December 2003, British Airways v. Commission, T-219/99, EU:T:2003:343, paragraphs 282-284.

${ }^{18}$ Ibid., paragraph 271.
} 
holding that the Commission was not required to show actual effects on the market resulting from the rebate schemes. It was enough if the Commission showed that the rebate schemes tended to restrict competition or were capable of having an anti-competitive effect. ${ }^{19}$ On appeal, British Airways argued that the General Court should have assessed the probable effects of its commissions, or take account of the evidence showing that they had no material effect. British Airways' appeal was dismissed by the Court, however, which stated that rebates which were neither quantity rebates nor fidelity rebates within the meaning of Hoffmann-La Roche had to be analysed with regard to their capability to produce exclusionary effects. ${ }^{20}$ It held that the General Court had rightly found the bonus schemes to be loyalty-inducing. ${ }^{21}$

Overall, the Court's and General Court's case law on rebate schemes subjects rebates to a mainly "qualitative analytical framework" 22 which has been characterised as formalistic. ${ }^{23}$ It regards loyalty-inducing rebates granted by dominant undertakings as an abuse contrary to Article 102 TFEU because it sees them as inherently capable of leading to a distortion of competition. This distortion is achieved through the rebates' influence on purchasers' freedom to purchase from whomever they choose, which is mirrored by the foreclosure of the dominant company's competitors. The requisite legal standard to which the Commission needs to prove anti-competitive effects has repeatedly been held to consist of a likely tendency or capability to restrict competition. There is no need to demonstrate actual effects on the market; potential effects (thus a capability to produce actual effects) are sufficient. This is considered an appropriate legal standard in the light of the special responsibility ${ }^{24}$ that companies with considerable market power have towards the competitive situation on the relevant market. This line of case law is often called form-based or formalistic because it presumes (possible or likely) competitive harm from

\footnotetext{
${ }^{19}$ Ibid., paragraph 293.

${ }^{20}$ Judgment of 28 September 2006, Van den Bergh v. Commission, C-552/03 P, EU:C:2006:607, paragraph 68.

${ }^{21}$ Ibid., paragraph 98.

${ }^{22}$ Nicolas Petit, "Intel, leveraging rebates and the goals of Article 102 TFEU”, European Competition Journal 11, no. 1 (2015): 36.

${ }^{23}$ Sofia Oliveira Pais, "Os descontos de exclusividade numa encruzilhada", in Estudos em Homenagem ao Conselheiro Presidente Rui Moura Ramos (Lisbon: Almedina, 2016, vol I), 1221.

${ }^{24}$ See, for instance, Judgment of 9 November 1983, Michelin I, 322/81, EU:C:1983:313, paragraph 57.
} 
the form of the rebates rather than focusing on the rebate scheme's actual effects on the market.

\subsection{Rebates in the Commission's 2009 Guidance Paper}

In February 2009, the European Commission issued a Guidance Paper on its enforcement priorities concerning exclusionary abuses under Article 102 TFEU. ${ }^{25}$ This was preceded by a Discussion Paper (2005) on the same questions. ${ }^{26}$ While some argue that the Commission should only rely on the Guidance Paper in order to decide which cases to pursue, ${ }^{27}$ the prevailing view is that the Guidance Paper will henceforth inform the analysis that the Commission carries out with respect to exclusionary abuses. ${ }^{28}$ In addition, it has been cautioned that in any case, companies align their market behaviour with the Commission's standard, rather than the Court's. ${ }^{29}$ This may ultimately make the question of enforcement priorities v. substantive guidance obsolete in practice.

The Guidance Paper contains a section exclusively dedicated to conditional rebates (paragraphs 37-46), in which the Commission explains based on which parameters it wants to select and analyse these rebates going forward. ${ }^{30}$ It starts from the premise that conditional rebates aim to reward buyers for their (favourable) purchasing behaviour, either through

\footnotetext{
${ }^{25}$ European Commission, Guidance Paper.

${ }^{26}$ In this Discussion Paper, the Commission made public some first reflections on a modernization of its approach to exclusionary abuses. Section 7.2.2 of that Paper (paragraphs 151-176) concerned conditional rebates. European Commission, DG Competition discussion paper on the application of Article 82 of the Treaty to exclusionary abuses (2005).

${ }^{27}$ This argument is, of course, supported by the title of the Guidance Paper, which only refers to enforcement priorities rather than to substantive guidance. On prioritization v. substantive guidance, see Wouter P. J. Wils, "The Judgment of the EU General Court in Intel and the so-called more economic approach to abuse of dominance", World Competition: Law \& Economics Review 37, no. 4 (2014): 408, 409; Richard Whish, "Intel v. Commission: Keep calm and carry on!", Journal of European Competition Law \& Practice 6, no. 1 (2014): 2 (highlighting that the Guidance Paper was not relied upon when selecting the Intel and Tomra cases, as the initiation of the latter predated the former).

${ }^{28}$ Similarly, see Paul Nihoul, "The ruling of the General Court in Intel: Towards the end of an effect-based approach in European Competition Law?", Journal of European Competition Law \& Practice 5, no. 8 (2014): 521; Giorgio Monti, "Article 82 EC: What future for the effects-based approach?”, Journal of European Competition Law \& Practice 1, no. 1 (2010): 5.

${ }^{29}$ Brian Sher, "Keep calm-yes; carry on-no! A response to Whish on Intel", Journal of European Competition Law \& Practice 6, no. 4 (2015): 220.

${ }^{30}$ For a summary of its as efficient competitor test, see also Nicholas Banasevic and Per Hellström, "When the chips are down: Some reflections on the European Commission's Intel decision", Journal of European Competition Law \& Practice 1, no. 4 (2010): 307-308.
} 
retroactive rebates or incremental ones. If granted by a company with substantial market power, conditional rebates may lead to anti-competitive foreclosure. ${ }^{31}$ The Commission regards them as a pricing abuse. ${ }^{32}$ The Guidance Paper does not condemn exclusivity rebates as such, but only in the case that they produce exclusionary effects. ${ }^{33}$ For this reason, the Commission holds that a number of factors should be considered when assessing the foreclosure effects of a rebate scheme: ${ }^{34}$ First of all, there are general factors that should form part of the analysis of any kind of exclusionary abuse, such as the market position of the dominant company, of its competitors and of its customers and suppliers, the conditions prevailing on the relevant market, the extent of the exclusionary conduct, possible evidence of actual foreclosure, and direct evidence of any exclusionary strategy. ${ }^{35}$ Secondly, there are factors specific to conditional rebates to be considered, namely the ability of as-efficient-competitors to compete for the contestable share of demand, ${ }^{36}$ and the retroactive nature of a rebate. ${ }^{37}$ In particular, the Commission intends to analyse whether a conditional rebate scheme "is capable of hindering expansion or entry even by competitors that are equally efficient." ${ }^{\prime 3}$ It will do so by calculating the price which a competitor would need to offer to the dominant company's customer in order to compensate it for losing the conditional rebate made available by the dominant company. This effective price is calculated for the relevant range, i.e. that portion of demand which a customer can direct away from the dominant company. ${ }^{39}$ The rebate's exclusivity-inducing effect is stronger the lower the price offered by the competitor needs to be in order to compete for the relevant range of demand. The Commission assumes, however, that prices above long-run average incremental cost (LRAIC) allow an as efficient competitor to compete profitably, ${ }^{40}$ while prices below

\footnotetext{
${ }^{31}$ European Commission, Guidance Paper, paragraph 37.

${ }^{32}$ Monti, "Article 82 EC", 4.

${ }^{33}$ Petit, "Intel", 41.

${ }^{34}$ European Commission, Guidance Paper, paragraph 38.

${ }^{35} \mathrm{Ibid}$., paragraph 38 referring to paragraph 20.

${ }^{36} \mathrm{Ibid}$., paragraph 39.

${ }^{37}$ Ibid., paragraph 40.

${ }^{38} \mathrm{Ibid}$., paragraph 41. More generally, the Commission regards conditional rebates as part of price-based exclusionary conduct, and intends to analyse them accordingly; see ibid., paragraph 41 referring to paragraphs $23-27$.

${ }^{39} \mathrm{Ibid}$., paragraph 41 . The relevant range also depends on the kind of rebate offered by the dominant company; see ibid., paragraph 42.

${ }^{40} \mathrm{Ibid}$., paragraph 43.
} 
average avoidable cost (AAC) are capable of foreclosing as efficient competitors. ${ }^{41}$ The Commission will also take into account whether a rebate is individualised or standardised, with the latter sometimes regarded as less harmful. ${ }^{42}$ As the Commission points out, it will take objective justifications based on efficiency into account provided they are passed on to customers. $^{43}$

AG Kokott has warned that even if the Commission adapted its decision practice based on its Guidance Paper, it continues to be bound by the Court's interpretation of Article 102 TFEU. ${ }^{44}$ In Post Danmark II, the Court reaffirmed that the Guidance Paper merely sets out the enforcement priorities of the Commission as a competition authority, and binds neither national competition authorities nor courts. ${ }^{45}$ Nevertheless, by relying on the effects-based spirit of the Guidance Paper in the cases it brings, the Commission is in a position to try and advance its economics-minded mission.

\subsection{First case law after the Guidance Paper: Tomra and Post Danmark II}

The first rebate case to stand the test of the Commission's more economic approach to Article 102 TFEU was Tomra. The Commission adopted its Tomra decision in 2006, i.e. after publishing its Discussion Paper but before issuing its Guidance Paper on Article 102 TFEU. Tomra had relied on exclusivity agreements, individualised quantity commitments and individualised retroactive rebate schemes in order to increase sales for its reverse vending machines. ${ }^{46}$ Although it considered it sufficient, under established case law, to demonstrate that a rebate tends to restrict competition, the Commission also analysed the likely effects of Tomra's rebates on the market for reverse vending machines. ${ }^{47}$ Upon appeal, the General Court held that this additional analysis carried out by the Commission

\footnotetext{
${ }^{41}$ Ibid., paragraph 44.

${ }^{42}$ Ibid., paragraph 45.

${ }^{43}$ Ibid., paragraph 46. It has been criticised, however, that the exact circumstances of when the Commission might accept such arguments are "rather cryptic"; see Damien Geradin, "Loyalty rebates after Intel: Time for the European Court of Justice to overrule Hoffman-La Roche", Journal of Competition Law and Economics 11, no. 3 (2015): 587.

${ }^{44}$ Advocate General Kokott's Opinion of 14 April 2011, Solvay v. Commission, C-109/10 P, EU:C:2011:256, paragraph 21.

${ }^{45}$ Judgment of 6 October 2015, Post Danmark II, C23/14, EU:C:2015:651, paragraph 52. On this see already European Commission, Guidance Paper, paragraph 3.

${ }^{46}$ Judgment of 9 September 2010, Tomra v. Commission, T155/06, EU:T:2010:370, paragraph 11.

${ }^{47}$ Commission Decision of 29 March 2006, Prokent-Tomra, COMP/E-1/38.113, paragraph 332.
} 
did not constitute the basis for its finding of an infringement of Article 102 TFEU, and that therefore it did not need to assess the accuracy of this additional economic analysis. Rather, the General Court again emphasised that it was enough to show that the rebates in question were capable to produce anti-competitive effects; proof of actual effects was not required. ${ }^{48}$ Capability to have an anti-competitive effect was therefore confirmed as the legal benchmark by which rebates are assessed. Tomra's appeal to the Court was dismissed in 2012, and the Court re-emphasised the General Court's reliance on capability to restrict competition as the applicable legal test. ${ }^{49}$ In particular, the Court agreed that no price/cost analysis had to be carried out in order to prove the anti-competitiveness of the individualised retroactive rebates at issue. ${ }^{50}$ The economic argument that certain rebates had no effect on the market was therefore defeated by the legal argument that they were capable of having an anti-competitive effect, ${ }^{51}$ without the need to engage in quantitative economic tests.

In a preliminary ruling of 2015, the Court got another opportunity to revisit its case law on rebates in the light of the Guidance Paper's economics-based approach. In Post Danmark II, the referring Danish court had specifically asked the Court to give it some legal guidance on the relevance of the AEC test for assessing rebates, and mentioned the Guidance Paper in order to substantiate its question on the relevance of less efficient competitors. ${ }^{52}$ While it did not directly set out three categories of rebates - as the General Court had done in Intel (see below) -, one can easily read the following three categories into the Court's Post Danmark II judgment: (1) quantity discounts linked solely to the volume of purchases and related to individual orders, which are regarded as legal, (2) loyalty rebates which are presumed to constitute an abuse of a dominant position, and (3) other types of rebates. ${ }^{53}$ In the case of third category rebates, all the circumstances of a case need to be taken into account in order to determine whether a rebate scheme is contrary to Article 102 TFEU. ${ }^{54}$ For these rebates, it needs to be shown that an anti-competitive effect is likely; a merely potential effect is

\footnotetext{
${ }^{48}$ Judgment of 9 September 2010, Tomra v. Commission, T155/06, EU:T:2010:370, paragraph 289.

${ }^{49}$ Judgment of 19 April 2012, Tomra v. Commission, C549/10 P, EU:C:2012:221, paragraph 68.

${ }^{50} \mathrm{Ibid}$., paragraph 73 .

${ }^{51}$ Ariel Ezrachi, EU Competition Law: An Analytical Guide to the Leading Cases, $5^{\text {th }}$ ed. (Oxford: Hart Publishing, 2016), 256.

${ }^{52}$ Judgment of 6 October 2015, Post Danmark II, C23/14, EU:C:2015:651, paragraph 20.

${ }^{53}$ Ibid., paragraphs $27-29$.

${ }^{54} \mathrm{Ibid}$., paragraph 50.
} 
sufficient in this regard. ${ }^{55}$ Importantly, the Court noted that in the case of third category rebates, an undertaking in a dominant position should be allowed to demonstrate that any alleged anti-competitive effects are counterbalanced or even outweighed by efficiencies, similar to an analysis under Article 101(3) TFEU. ${ }^{56}$ The Court also emphasised that the asefficient-competitor (AEC) test may constitute a useful analysis within the context of Article 102 TFEU, although it is not as such required by the (case) law. ${ }^{57}$ It is merely "one tool amongst others". ${ }^{58}$

These two rebate cases were closely followed as they could have sealed the fate of the AEC test. Tomra, for one, needs to be regarded as a failed attempt at introducing a more economics-based analysis into this area of the law. Considering that the case was initiated when the debate on the Guidance Paper merely got started, this does not necessarily reflect on the Guidance Paper's power to induce a more economics-based approach into the antitrust assessment of rebates. Post Danmark II, on the other hand, was decided several years after the adoption of the Guidance Paper, and a year after the General Court had dismissed Intel's appeal of the Commission decision..$^{59}$ Post Danmark II saw the AEC test favourably mentioned and accepted as one possible analytical tool. This can certainly be regarded as a first tentative step by the Court in the Commission's effects-based direction. However, the Court was quite clear that other types of analysis were (at least) equally valid. Some even labelled Post Danmark II a "great disappointment" for those who wanted to see the AEC test morph into proper good law. ${ }^{60}$ Nevertheless, it certainly allowed the Commission's new economics-based approach a foot in the door in the realm of rebates, without opening it all the way.

\footnotetext{
${ }^{55}$ Ezrachi, EU Competition Law, 263.

${ }^{56}$ Judgment of 6 October 2015, Post Danmark II, C23/14, EU:C:2015:651, paragraphs 47-49.

${ }^{57} \mathrm{Ibid}$., paragraphs 57-58. Thereby, it has been argued, the Court agreed with the General Court's stance on the AEC in its Intel ruling; see Miroslava Marinova, "Should the rejection of the 'as efficient competitor' test in the Intel and Post Danmark II judgments lead to dismissal of the effectbased approach?", European Competition Journal 12, no. 2-3 (2016): 392.

${ }^{58}$ Judgment of 6 October 2015, Post Danmark II, C23/14, EU:C:2015:651, paragraph 61.

${ }^{59}$ See below, section 3.2 .

${ }^{60}$ Björn Lundqvist, "Post Danmark II, now concluded by the ECJ: Clarification of the rebate abuse, but how do we marry Post Danmark I with Post Danmark II?", European Competition Journal 11, 2-3 (2015): 573.
} 


\section{The Intel case (so far): shaping the future of loyalty rebates}

Good things come to those who wait - at least that might be Intel's mantra at the moment. Its rebate case has been going on for almost two decades, and there is no end in sight. A short overview shall help place the major milestones in the Intel case on the time horizon: The Intel case was initiated by a complaint that Intel's competitor AMD lodged with the European Commission in the year 2000. ${ }^{61}$ On 26 July 2007, the European Commission started official proceedings against Intel by sending the company a statement of objections concerning rebates that Intel was alleged to have relied upon in order to induce loyalty among its customers. This statement of objections was supplemented on 17 July 2008. After the Commission fined Intel by decision of May 2009, ${ }^{62}$ the General Court rejected its appeal in June 2014. Intel appealed the General Court's judgment and, by the time Advocate General (AG) Wahl delivered his opinion in October 2016, the antitrust community was anxiously awaiting the Court of Justice's final judgment in the case, which was rendered on 6 September 2017. Today, we stand in front of a judgment that answers some legal questions but raises many more - and rather than deciding the Intel case for good the Court of Justice remanded it back to the General Court. In the following, the different chapters of the Intel saga are discussed in turn, culminating in a discussion of the most recent judgment.

\subsection{The Commission's decision}

The European Commission issued its Intel decision on 13 May 2009, levying a then-record EUR 1.06 billion fine for two abuses of a dominant market position, the first of which will be examined hereafter. This abuse was a rebate scheme for a number of OEMs (Dell, Lenovo, HP and NEC) and a distributor. Intel's rebate scheme was said to foreclose competitors by requiring the OEMs to buy (most of) their central processing units or CPUs from Intel, or the distributor not to stock computers which did not contain CPUs by Intel. ${ }^{63}$

\footnotetext{
${ }^{61}$ A second complaint followed in 2003; see Commission Decision of 13 May 2009, Intel, COMP/C-3/37.990.

${ }^{62} \mathrm{~A}$ few weeks after the decision was issued, the European Ombudsman found that the European Commission had acted against principles of good administration in its investigation; see Decision of the European Ombudsman of 14 July 2009 closing his inquiry into complaint 1935/2008/FOR against the European Commission.

${ }^{63}$ Commission Decision of 13 May 2009, Intel, COMP/C-3/37.990. For a summary of the decision, see 2009 OJ C227/13. The second abuse ("naked restrictions") were payments to OEMs so
} 
The Commission acknowledged that its Guidance Paper was not applicable to the Intel case, as it was issued after the statements of objections were handed to Intel. Nevertheless, it considered that its Intel decision was fully in line with the considerations in the Guidance Paper, ${ }^{64}$ as detailed above. Relying on the terminology used in its Guidance Paper, the Commission referred to conditional rebates in its decision.

The first part of the Commission's analysis relied on the Court's case law, holding that conditional rebates such as the ones granted by Intel constituted an infringement of Article 102 TFEU. It rebutted Intel's assertion that the case law required a demonstration of actual foreclosure in order to find an infringement of Article 102 TFEU, referring to the General Court's judgments in British Airways and Michelin II in which the General Court had relied on capability to have anti-competitive effects as its legal test. ${ }^{65}$ It underlined that this analysis was sufficient for finding an infringement. ${ }^{66}$ The Commission's analysis based on this "formalistic" case law has been criticised by commentators close to Intel. ${ }^{67}$ However, this criticism appears to brush aside the fact that the Commission is indeed bound by this case law, ${ }^{68}$ meaning that its bifurcated analysis under both the case law and its own economic approach as outlined in the Guidance Paper might be the only way to advance its more economics-based approach under Article 102 TFEU.

as to prevent or delay the sale of rival products. Another facet of the Intel case was the "procedural arrogance" (Luca Mazzone and Alberto Mingardi, "Innovation, competition and antitrust: An examination of the Intel case", Economic Affairs 31, no. 2 (2011): 69) which the Commission was accused of, which led to a finding by the European Ombudsman that the Commission had "infringed principles of good administration" by "failing to make an adequate written note of the meeting [with Dell] of 23 August 2006, for the purposes of establishing agreed minutes of that meeting." Decision of the European Ombudsman of 14 July 2009 closing his inquiry into complaint 1935/2008/FOR against the European Commission.

${ }^{64}$ Commission Decision of 13 May 2009, Intel, COMP/C-3/37.990, paragraph 916.

${ }^{65} \mathrm{Ibid}$., paragraphs 919, 922 with reference to Judgment of 17 December 2003, British Airways $v$. Commission, T-219/99, EU:T:2003:343, paragraph 293 (direct quote); Judgment of 30 September 2003, Michelin II, T-203/01, EU:T:2003:250, paragraph 239.

${ }^{66}$ Commission Decision of 13 May 2009, Intel, COMP/C-3/37.990, paragraph 925, paragraphs 9261001 for the analysis.

${ }^{67}$ Damien Geradin, "The decision of the Commission of 13 May 2009 in the Intel case: Where is the foreclosure and consumer harm?", Journal of European Competition Law \& Practice 1, no. 2 (2010): 113, 115. On Professor Geradin's ties with Intel, see Banasevic and Hellström, "When the chips are down", 303 n 17.

${ }^{68}$ Clearly acknowledging this limitation, see European Commission, Guidance Paper, paragraph 3. 
In addition to its legal analysis based on authoritative case law, the Commission carried out the as-efficient-competitor (AEC) test for each customer to which Intel had granted rebates, and concluded that the rebates were capable of anti-competitive foreclosure effects. ${ }^{69}$ On over 150 pages of the decision, the Commission thus set out to show, based on price/ cost factors, that Intel's rebate scheme was capable of causing, or likely to cause, foreclosure on the market for x 86 CPUs. ${ }^{70}$ The AEC test carried out internally by Intel reached the reverse conclusion, namely that its rebates were not capable of foreclosing as efficient competitors. In essence, Intel and the Commission disagreed on the results from a test which is conceptually one and the same, particularly as regards the delineation of the contestable share of the market for x86 CPUs. ${ }^{71}$

\subsection{The General Court's judgment}

On 12 June 2014, the General Court dismissed Intel's appeal of the Commission's infringement decision, a judgment which was controversial to say the least. ${ }^{72}$ Its significance was understood to go far beyond the case at hand, having repercussions not only on the legal analysis of rebates under Article 102 TFEU but also on the Commission's more economics-based approach to single firm behaviour. ${ }^{73}$ The General Court based its analysis on a three-prong legal categorisation of rebates: (1) quantity rebates, (2) exclusivity rebates, ${ }^{74}$ and (3) third category rebates. ${ }^{75}$ This categorisation in turn relied on its reading of Michelin I and British Airways. ${ }^{76}$ While quantity rebates refer to volume-based savings that the supplier passes on to his

\footnotetext{
${ }^{69}$ Banasevic and Hellström, "When the chips are down", 304.

${ }^{70}$ Commission Decision of 13 May 2009, Intel, COMP/C-3/37.990, paragraph 916, paragraphs 1002-1640.

${ }^{71}$ On this see Geradin, "The decision of the Commission”, 118.

${ }^{72}$ Some have even referred to the judgment's reception as hugely hostile; see Whish, "Intel $v$. Commission”, 1.

${ }^{73}$ James S. Venit, "Case T-286/09 Intel v. Commission - The judgment of the General Court: All steps backward and no steps forward”, European Competition Journal 10, no. 2 (2014): 204.

${ }^{74}$ Noting that the General Court's reference to "exclusivity rebates" directly references the theory of harm that is seen in those rebates, much more so than the previously often used terms fidelity or loyalty rebates, see Richard Whish and David Bailey, Competition Law, $8^{\text {th }}$ ed. (Oxford: Oxford University Press, 2015), 770 n 97.

${ }^{75}$ Judgment of 12 June 2014, Intel v. Commission, T-286/09, EU:T:2014:547, paragraphs 74-88.

${ }^{76}$ Judgment of 12 June 2014, Intel v. Commission, T-286/09, EU:T:2014:547, paragraph 74; Judgment of 9 November 1983, Michelin I, 322/81, EU:C:1983:313, paragraphs 71-73; Judgment of 15 March 2007, British Airways v. Commission, C-95/04 P, EU:C:2007:166, paragraphs 62-68.
} 
customer and are generally viewed as legitimate, exclusivity rebates are conditional upon the customer obtaining all or most of its requirements from the dominant company and are presumed to be anti-competitive by the case law. Third category rebates, then, are rebates that are not explicitly conditioned upon exclusive dealing but are nevertheless loyalty-inducing. Only the latter call for an assessment of all the circumstances of the case, in the view of the General Court. ${ }^{77}$ This categorisation essentially regards exclusivity rebates as abuses of dominance by object - to use terminology borrowed from Article 101 TFEU -, and third category rebates as abuses of dominance by effect. Necessarily, this has implications for the legal assessment of these types of rebates. A similar - albeit less forceful - wording was adopted by the Court of Justice a year later in Post Danmark II, where it held that in the case of third type rebates all the circumstances of a case had to be assessed in order to determine whether a rebate scheme was capable of restricting competition. ${ }^{78}$

The General Court found that the rebates at stake in Intel concerned exclusivity rebates of the second category, ${ }^{79}$ and that these "are by their very nature capable of restricting competition" 80 and of tying customers to the dominant company ${ }^{81}$ - thus making an analysis of their (potential) effects irrelevant. As exclusivity rebates "automatically satisf[y]" the criterion of capability, it makes little sense to engage in an elaborate economic analysis of actual effects. ${ }^{82}$ Thus, the General Court ruled that where a dominant company grants an exclusivity rebate, the rebates' actual effects on competition do not have to be assessed..$^{83}$ Exclusivity rebates granted by dominant companies will normally bring about the effect which they are intended to bring about, and consequently they are seen as inherently anticompetitive without any further need to prove actual effects. The General Court held such exclusivity rebates to be "incompatible with the objective of undistorted competition" ${ }^{\prime 4}$ on the internal market. This objective, it has

\footnotetext{
${ }^{77}$ Judgment of 12 June 2014, Intel v. Commission, T-286/09, EU:T:2014:547, paragraph 78.

${ }^{78}$ On this, see already above at section 2.3 and Judgment of 6 October 2015, Post Danmark II, C23/14, EU:C:2015:651, paragraphs 28-29.

${ }^{79}$ Judgment of 12 June 2014, Intel v. Commission, T-286/09, EU:T:2014:547, paragraph 79.

${ }^{80}$ Ibid., paragraph 85 .

${ }^{81}$ Ibid., paragraph 86.

${ }^{82}$ Nihoul, "The ruling of the General Court in Intel", 523.

${ }^{83}$ Judgment of 12 June 2014, Intel v. Commission, T-286/09, EU:T:2014:547, paragraph 103.

${ }^{84}$ Ibid., paragraph 77. See also Wils, “The judgment of the EU General Court in Intel”, 424.
} 
been held, is the ultimate goal which necessarily needs to guide any economic approach to Article 102 TFEU. ${ }^{85}$

As the Court has done in previous cases, the General Court considered that exclusivity rebates "are designed to remove or restrict the purchaser's freedom to choose his sources of supply and to deny other producers access to the market." ${ }^{\prime 86}$ It suffices if access to the relevant market is made more difficult for competitors through the exclusivity rebate, market access does not have to be made altogether impossible. ${ }^{87}$ As the AEC test can only confirm the latter, the General Court considered that it was not necessary to carry it out. ${ }^{88}$ The General Court thus understands the abuse of a dominant position in the case of rebates to go beyond what the AEC test can ascertain, and as a consequence the AEC test is regarded as too narrow and thus not applicable.

The General Court's judgment tries to show that considerations of an economic nature do play into its analysis, for instance by referring to the possibility for the dominant undertaking to leverage its power over the non-contestable share of the market for its own benefit in the contestable share. ${ }^{89}$ By this, it has been said, the General Court highlights that an "economic theory of harm underpins the prohibition of dominant firms' rebates." ${ }^{90}$ However, this did not lead it to regard economics-based tests as a necessity. It also relied on Tomra for its argument that the AEC test was irrelevant for the purposes of exclusivity rebates. ${ }^{91}$

The General Court held that in order to find that an exclusivity rebate amounts to an abuse under Article 102 TFEU, it is not necessary to show that it is capable to restrict competition in a specific case; all the circumstances of a case only need to be assessed for third category rebates. ${ }^{92}$ For the General Court, the capability to produce anti-competitive effects is

\footnotetext{
${ }^{85}$ Ibid., 417; see also p. 420 on the integration of legal and economic analysis. Holding against this that "early per se intervention does not serve the goal of protecting the competitive process" in cases in which the competitive effects of a certain business behaviour are not known, see Patrick Rey and James S. Venit, "An effects-based approach to Article 102: A response to Wouter Wils", World Competition: Law \& Economics Review 38, no. 1 (2015): 23.

${ }^{86}$ Judgment of 12 June 2014, Intel v. Commission, T-286/09, EU:T:2014:547, paragraph 77.

${ }^{87}$ Ibid., paragraph 88.

${ }^{88}$ Ibid., paragraph 150.

${ }^{89}$ See ibid., paragraphs 92-93.

${ }^{90}$ Petit, "Intel", 37. This, however, means that only those exclusivity rebates which lead to leveraging are covered by the strict legal standard prohibiting rebates as such; see ibid., 37, 43.

${ }^{91}$ Judgment of 12 June 2014, Intel v. Commission, T-286/09, EU:T:2014:547, paragraph 153.

${ }^{92}$ Ibid., paragraphs 81-84, 143.
} 
sufficient consideration of effects as regards dominant undertakings "anticompetitive effects were clearly produced by the practices adopted by Intel." 93 This case law of the General Court - and the cases preceding it - has been called effects-based, though perhaps not in the way that Chicagoan economics would see fit. ${ }^{94}$ The General Court further held that no AEC test needs to be carried out to support the conclusion that a rebate is anti-competitive, neither for exclusivity rebates nor for third category rebates. ${ }^{95}$ The Commission does not need to prove direct damage to consumers, nor a causal link between consumers' damage and the exclusivity rebates under investigation, as Article 102 TFEU also discourages anticompetitive practices which may affect consumers through their "impact on an effective competition structure". ${ }^{96}$

The General Court distinguished exclusivity rebates from abusive pricing practices, holding that it is not the level of the price as such which is seen as abusive in the case of rebates, but the exclusivity which flows from them. ${ }^{97}$ Some commentators have commended this approach, underlining that the harm to competition that flows from exclusivity rebates is different from the harm that predatory pricing brings about. ${ }^{98} \mathrm{AG}$ Wahl, however, disagrees with this differentiation..$^{99}$

While the General Court's Intel judgment has been said to be fully in accordance with the line of case law starting with Hoffmann-La Roche, critics have called for this case law to be replaced with a more effects-based reading of Article 102 TFEU. ${ }^{100}$ An aspect of the judgment which was widely commented on - and criticised - was the fact that the General Court held that there was no de minimis threshold for abuses of a dominant position,

\footnotetext{
${ }^{93}$ Nihoul, "The ruling of the General Court in Intel", 528.

${ }^{94}$ Ibid., 530.

${ }^{95}$ Judgment of 12 June 2014, Intel v. Commission, T-286/09, EU:T:2014:547, paragraphs 144, 146, 153.

${ }^{96} \mathrm{Ibid}$., paragraph 105 with reference to Judgment of 15 March 2007, British Airways v. Commission,

C-95/04 P, EU:C:2007:166, paragraph 106.

${ }^{97}$ Judgment of 12 June 2014, Intel v. Commission, T-286/09, EU:T:2014:547, paragraph 99.

${ }^{98}$ Wils, "The judgment of the EU General Court in Intel", 428. In selective price cuts, the Court had held price/cost tests to be applicable; see Judgment of 27 March 2012, Post Danmarkv. Konkurrencerådet (Post Danmark I), C-209/10, EU:C:2012:172, paragraphs 35-38.

${ }^{99}$ Advocate General Wahl's Opinion of 20 October 2016, Intel v. Commission, C-413/14 P, EU:C:2016:788, paragraph 102.

${ }^{100}$ Geradin, "Loyalty rebates after Intel”, 597, 614; Venit, “Case T-286/09 Intel v. Commission”, 208209.
} 
so that even foreclosure from a relatively low share of worldwide demand (in Intel: $14 \%$ ) was seen as sufficient. ${ }^{101}$

\subsection{Advocate General Wahl's opinion}

AG Nils Wahl delivered his opinion on Intel's appeal of the General Court's judgment in October 2016. He scrutinised the General Court's Intel judgment very closely, suggesting to the Court that it should be annulled on a number of both procedural and substantive grounds. In the following, only his analysis of the rebates themselves will be scrutinised. He also regarded this as the central question which Intel's appeal posed to the Court: Are loyalty rebates of the Intel type inherently anti-competitive, meaning that it is not necessary to consider all the circumstances of the case in order to decide whether they are capable of restricting competition on the relevant market? ${ }^{102}$

Intel refuted the General Court's finding that its exclusivity rebates were inherently capable of restricting competition. ${ }^{103}$ The AG pointed out that the decisive question was: which was the correct legal test under which such loyalty rebates need to be analysed? ${ }^{104}$ The AG reached the conclusion that the relevant case law calls for an assessment of all the circumstances in all rebate cases, as the Court - particularly in Hoffmann-La Roche - has only ever made findings of unlawfulness after having carried out a comprehensive assessment of the legal and economic context ("all the circumstances" of the case in the terminology used under Article 102 TFEU), i.e. the conditions under which rebates were granted and their market coverage. ${ }^{105}$ This is also how the AG reads the Court's preliminary ruling in Post Danmark $I I,{ }^{106}$ although this is perhaps not the only possible reading of that case..$^{107}$

\footnotetext{
${ }^{101}$ Judgment of 12 June 2014, Intel v. Commission, T-286/09, EU:T:2014:547, paragraphs 116, 194. On this criticism, see Sher, "Keep calm-yes; carry on-no!", 219; Venit, "Case T-286/09 Intel v. Commission", 216-218; Whish, "Intel v. Commission", 2; Advocate General Wahl's Opinion of 20 October 2016, Intel v. Commission, C-413/14 P, EU:C:2016:788, paragraphs 137-146, 177.

${ }^{102}$ Advocate General Wahl's Opinion of 20 October 2016, Intel v. Commission, C-413/14 P, EU:C:2016:788, paragraph 4.

${ }^{103}$ Ibid., paragraph 49.

${ }^{104}$ Ibid., paragraph 52.

${ }^{105}$ Ibid., paragraphs 66, 68, 74 .

${ }^{106}$ Ibid., paragraph 76.

${ }^{107}$ The following sections of Post Danmark II appear to suggest a reading more in line with the General Court in Intel: Judgment of 6 October 2015, Post Danmark II, C23/14, EU:C:2015:651, paragraphs 27-29. Arguing that Post Danmark II should not be read in this way, see Advocate
} 
The AG did not concur with the General Court's three-part categorisation of rebates, holding instead that the case law only distinguishes between two categories: volume-based rebates and all types of loyalty rebates. In the case of the latter, the AG recognised parallels with restrictions by object under Article 101 TFEU. ${ }^{108}$

Concerning the General Court's alternative assessment of the rebates' capability to restrict competition, the AG strongly disagreed with the judgment under appeal. He held that while the Commission does not need to show actual effects, its capability analysis must go beyond the hypothetical or theoretically possible. The terms "capability" and "likelihood" as used in the case law are one and the same. ${ }^{109}$ For a foreclosure effect to satisfy the legal standard of Article 102 TFEU, it is not enough that it "appears more likely than not." ${ }^{110}$ Otherwise, this would amount to a legal standard based on the form of the conduct rather than its anti-competitive effects. ${ }^{111}$ The Advocate General then assessed the General Court's analysis against this background, finding that its assessment was not conclusive. In particular, he argued that while there was no legal obligation to rely on the AEC test, as the Commission carried it out it should not have been ignored. ${ }^{112}$

\subsection{The Court of Justice's landmark judgment}

Defying expectations and wishes on all sides - that the Court uphold the General Court's Intel judgment ${ }^{113}$ or quash the Commission decision ${ }^{114}$

General Wahl's Opinion of 20 October 2016, Intel v. Commission, C-413/14 P, EU:C:2016:788, paragraphs 104-105.

${ }^{108}$ Ibid., paragraphs 81-82.

${ }^{109}$ Ibid., paragraphs 114-115. There is no universal agreement on this; see Pablo Ibáñez Colomo, "Comments on Case C-413/14 P, Intel: Presumptions, effects-based analysis and open questions", Chillin'Competition Blog, 2017, https://chillingcompetition.com/2017/09/06/comments-on-intelpresumptions-effects-based-analysis-and-open-questions/. In any case, the Court's judgment in Intel only refers to capability.

${ }^{110}$ Advocate General Wahl's Opinion of 20 October 2016, Intel v. Commission, C-413/14 P, EU:C:2016:788, paragraph 117.

${ }^{111}$ Ibid., paragraph 118. For a critical assessment of this aspect of the Opinion, see Clarke, "The Opinion of AG Wahl in the Intel rebates case", 267.

${ }_{112}$ Advocate General Wahl's Opinion of 20 October 2016, Intel v. Commission, C-413/14 P, EU:C:2016:788, paragraphs 169, 170.

${ }^{113}$ See, for instance, Whish, "Intel v. Commission"; Wils, “The judgment of the EU General Court in Intel".

${ }^{114}$ See, for instance, Geradin, "Loyalty rebates after Intel"; Venit, "Case T-286/09 Intel v. Commission"; Advocate General Wahl's Opinion of 20 October 2016, Intel v. Commission, C-413/14 P, EU:C:2016:788. 
-, the Grand Chamber of the Court of Justice decided to take a different path when it resolved Intel's appeal on 6 September 2017: in an unexpected and unusual turn of events, it set the General Court's judgment aside and remanded the case back to the General Court after clarifying some - but by far not all ${ }^{115}$ - legal issues pertaining to the legal assessment of rebates under Article 102 TFEU.

\subsubsection{General remarks}

The Court pointed out, first of all, that Article 102 TFEU does not prohibit the holding of a dominant position, but only its abuse. At the same time, Article 102 TFEU does not intend to protect competitors which are less efficient than the dominant undertaking. ${ }^{116}$ The latter statement, it has been argued by Intel counsel, paves the way for the logic underlying the AEC test. ${ }^{117}$ The Court then reiterated dominant undertakings' special responsibility to allow for genuine, undistorted competition on the European internal market. ${ }^{118}$ It referred to two infringements of Article 102 TFEU: pricing abuses that foreclose as efficient competitors, and conduct that strengthens a company's dominant position "by using methods other than those that are part of competition on the merits." 119 Through this positioning, it appears that the Court considers loyalty rebates to form part of the broader category of pricing abuses, an abuse category for

\footnotetext{
${ }^{115}$ Bearing in mind the considerable length of the Commission decision $(1,803)$, the General Court's judgment (1,647 paragraphs) and even the Advocate General's Opinion (349 paragraphs), the Court made do with a short judgment covering a mere 151 paragraphs. Of these, only 19 paragraphs concern the antitrust assessment of rebates. Just like market shares do not give a full picture of a company's position on the relevant market, these numbers in themselves do in no way relate to the quality of the judgments. They indicate, however, that the Court's judgment may have left a number of issues pertaining to the antitrust assessment of rebates unaddressed - issues which are to be resolved by the Court in the future. And indeed, the Court held that it did not need to address Intel's second, third and sixth ground of appeal; Judgment of 6 September 2017, Intel v. Commission, C-413/14 P, EU:C:2017:632, paragraph 147.

${ }^{116}$ Ibid., paragraph 133. However, see the Guidance Paper's recognition that less efficient competitors may, in some instances, also exert a competitive constraint; European Commission, Guidance Paper, paragraph 24. Similarly arguing in this vein, see Oliveira Pais, "Os descontos de exclusividade", 1237.

${ }^{117}$ James S. Venit, “The judgment of the European Court of Justice in Intel v. Commission: A procedural answer to a substantive question?", European Competition Journal 13, nos. 2-3 (2017): 180. ${ }^{118}$ Judgment of 6 September 2017, Intel v. Commission, C-413/14 P, EU:C:2017:632, paragraph 135.

${ }^{119}$ Ibid., paragraph 136.
} 
which it has previously held that all the circumstances of a case need to be assessed when analysing a company's behaviour in this regard. ${ }^{120}$

\subsubsection{Clarification of Hoffmann-La Roche}

Referring to Hoffmann-La Roche, the Court stated that exclusive dealing arrangements by a dominant supplier infringe Article 102 TFEU, no matter whether or not a rebate is granted in exchange for an exclusive dealing obligation. By the same token, loyalty rebates - which do not contain a formal exclusive purchasing obligation - breach Article 102 TFEU. ${ }^{121}$ In making this statement, the Court confirms one of the central tenets of Hoffman-La Roche, namely that such conduct continues to be legally presumed to be anti-competitive, i.e. capable of restricting competition. ${ }^{122}$ While the Court did not explicitly refer to the three-prong categorisation of rebate schemes applied by the General Court in making these statements, it only described rebates that belong to the second category which the General Court had made out, namely rebates which require the customer to obtain all or most of its requirements from the dominant supplier. There is no mention of the third category of rebates, i.e. rebates without an exclusivity condition which may nevertheless be loyalty-inducing. This could indicate that the categorisation which the General Court deduced from the case law (particularly, Hoffmann-La Roche, Michelin I and British Airways) stands as a matter of principle, thus deciding against the AG's recommendation in this regard.

What follows (paras 138-141) is the Court's "clarification" of the Hoffmann-La Roche case law: the Court's more modern take on this venerable precedent. It pertains to rebate schemes which contain an exclusivity clause, and shows how the legal presumption that such a rebate scheme is abusive can be rebutted. The Court's clarification applies to cases "where the undertaking concerned submits, during the administrative procedure, on the basis of supporting evidence, that its conduct was not capable of restricting competition and, in particular, of producing the alleged foreclosure effects." ${ }^{\prime 23}$ It is interesting to note at this point that this is precisely the argument that was made by the dominant company in the cases of

\footnotetext{
${ }^{120}$ See, for instance, Judgment of 17 February 2011, Konkurrensverket v. TeliaSonera Sverige, C-52/09, EU:C:2011:83, paragraphs 28, 76.

${ }^{121}$ Judgment of 6 September 2017, Intel v. Commission, C-413/14 P, EU:C:2017:632, paragraph 137.

122 Similarly, see Ibáñez Colomo, "Comments on Case C-413/14 P".

${ }^{123}$ Judgment of 6 September 2017, Intel v. Commission, C-413/14 P, EU:C:2017:632, paragraph 138.
} 
Michelin II and British Airways - and which was back then rejected by the Courts. This clarification therefore reads like a considerable re-interpretation of the Courts' own case law.

Where such a submission is made by the dominant company, the Commission is required to carry out an analysis of the rebates' capacity to foreclose competitors. The Court names a number of factors which the Commission should take into account in such an analysis, namely "the extent of the undertaking's dominant position on the relevant market, [...] the share of the market covered by the challenged practice, as well as the conditions and arrangements for granting the rebates in question, their duration and their amount." ${ }^{124}$ Intent to exclude as-efficient-competitors is another factor that needs to be considered. For this last factor, the Court refers to Post Danmark I by analogy, a case which concerned selective price cutting. ${ }^{125}$ This can be seen as another indication that the antitrust assessment of rebates is set to be more aligned with (other) pricing abuses.

In order to assess whether a rebate scheme may benefit from an objective justification, the Court states that same factors which need to be considered for assessing a rebate scheme's capacity to foreclose are to be taken into account. In addition, however, efficiency may be relied upon to counterbalance or even outweigh any foreclosure effect arising from the rebate scheme. The Court emphasises that objective justification is a separate analytical step that must only be carried out once it has been established that the rebate scheme at issue effectively has the capacity to foreclose as-efficient-competitors. ${ }^{126}$

\subsubsection{Envisioning the practical application of the judgment}

The Court seems to suggest (para 138) that the particular circumstances of the case which it lists in paragraph 139 are only to be analysed in the case that the dominant undertaking tries to rebut the presumption of illegality by arguing that its conduct was not capable of restricting competition, based on supporting evidence. According to the Court, this submission on the part of the dominant undertaking would then have to incite the Commission to carry out an in-depth analysis of the factors mentioned. This leads to a situation in which the Commission makes a prima facie argument that a loyalty rebate scheme infringes Article 102 TFEU

\footnotetext{
${ }^{124}$ Ibid., paragraph 139.

${ }^{125}$ Judgment of 27 March 2012, Post Danmark I, C-209/10, EU:C:2012:172, paragraph 29.

${ }^{126}$ Judgment of 6 September 2017, Intel v. Commission, C-413/14 P, EU:C:2017:632, paragraph 140.
} 
(presumption of unlawfulness), upon which the undertaking concerned submits evidence that its conduct did not restrict competition - in particular because it did not foreclose competitors -, and only then would the Commission take into account all the circumstances of the case: the company's market position, the market coverage of the rebate scheme, the specifics of the rebates at stake (conditions for granting them, duration, amount), and the existence or not of a foreclosure strategy. What is not clear is how detailed the dominant undertaking's evidence, supporting its claim that its rebate scheme was not capable of restricting competition, needs to be. If that threshold is sufficiently low, then the initial presumption of unlawfulness will in any case give way to an in-depth analysis of all the circumstances ("effects"). This is also what is suggested by first reactions from law firms to the Intel judgment. It has been held elsewhere that there needs to be at least "a plausible claim [...] that the dominant firm's conduct may not have been capable of foreclosing its rivals". ${ }^{127}$ Is this what the Court intended to propose? If so, then the three-prong categorisation of rebates, which distinguishes between rebate schemes that are anticompetitive as such (by object) or because they are loyalty-inducing (by effect), will be reduced to a two-prong categorisation as soon as the dominant company submits evidence that its loyalty rebates were not capable of foreclosing as-efficient-competitors. ${ }^{128}$ This outcome would then be in line with the arguments of AG Wahl as discussed above.

In addition, it is unlikely that the Commission will make any claims as to the anti-competitiveness of rebate schemes without also considering (or indeed fully carrying out) the analysis of all the factors of the case as sketched out by the Court. More likely, the Commission's first analysis will already incorporate these factors. This again erodes any distinction between rebates of the second and third category - if indeed, there ever was such a clear separation.

\subsubsection{No pick and choose approach - even for the sake of completeness}

If the Commission finds that a rebate scheme infringes Article 102 TFEU, in an analysis of all the circumstances of the case based on the factors listed in para 139 in order to ascertain the conduct's capability to foreclose,

\footnotetext{
${ }^{127}$ Venit, "The judgment of the European Court of Justice in Intel v. Commission", 182.

${ }^{128}$ In a similar vein, see Pablo Ibáñez Colomo, "More on Intel: Some thoughts after the IBA Conference in Florence”, Chillin'Competition Blog, 12 September 2017, https://chillingcompetition.com/2017/09/12/more-on-intel-some-thoughts-after-the-iba-conference-in-florence/.
} 
then it is for the General Court to "examine all of the applicant's arguments seeking to call into question the validity of the Commission's findings concerning the foreclosure capability of the rebate concerned." ${ }^{29}$ In Intel, the Commission undertook a bifurcated analysis that was recalled above: one based on the case law and finding that Intel's rebate scheme was intrinsically capable of restricting competition, and another one based on the circumstances of the case, including an elaborate AEC test. The latter found that the rebate scheme was capable of foreclosing as-efficientcompetitors as they would have to offer prices below cost. ${ }^{130}$ From this, the Court concluded that the AEC test constituted an important element in the Commission's analysis of the rebate scheme's capability to foreclose. ${ }^{131}$ Consequently, it was for the General Court to "examine all of Intel's arguments concerning that test." ${ }^{132}$ In its judgment, the General Court had not regarded the AEC test as of significance, and took into account neither the Commission's execution of that test nor Intel's arguments pointing out faults in the Commission's test. ${ }^{133}$ This error was sufficiently grave for the Court to set aside the General Court's Intel judgment. ${ }^{134}$ As the Court considered that the state of proceedings did not allow it to give a final judgment in the case, it referred the case back to the General Court. That Court was instructed to review the rebate scheme's capability to restrict competition by relying on factual and economic evidence, and to take into account Intel's arguments in this respect.

The Court already gave a first indication that it views the AEC test as an acceptable tool within the sphere of rebates in Post Danmark II (see above). This was implicitly confirmed in Intel, where the Court set aside the General Court's judgment based on its failure to take into account Intel's counter-argument to the Commission's AEC test. However, Intel only clarifies that the General Court needs to review Intel's counter-arguments to the Commission's AEC test because the Commission carried it out. What it does not do is elevate the AEC test to a necessary element in the legal framework of rebates.

\footnotetext{
${ }^{129}$ Judgment of 6 September 2017, Intel v. Commission, C-413/14 P, EU:C:2017:632, paragraph 141.

${ }^{130} \mathrm{Ibid}$., paragraph 142.

${ }^{131}$ Ibid., paragraph 143.

${ }^{132}$ Ibid., paragraph 144.

${ }^{133}$ Ibid., paragraphs 145-146.

${ }^{134} \mathrm{Ibid}$., paragraph 147.
} 
While members of DG COMP had suggested at the time when the Commission's decision was published that Intel would showcase "how the Commission can combine established case law with a modern, effectsbased analysis", ${ }^{135}$ it is fair to say that this experiment was not crowned with considerable success before the Court. Rather to the contrary, the Court's judgment demonstrates that the Commission, if relying on additional economic analysis which it is not required to engage in by established case law, ${ }^{136}$ will also need to diligently respond to companies' counter-arguments in that respect. It cannot at a later stage deny its own economic analysis and hope to win the case based on the Court's case law alone.

\subsubsection{De minimis threshold under Article 102 TFEU?}

There are a number of issues which the Court did not address in its Intel judgment, most pressingly the question of a de minimis threshold for Article 102 TFEU infringements. It did, however, list market coverage as one of the factors to be taken into account in an analysis of all the circumstances of the case. ${ }^{137}$ This might hint at the possibility that the Court understands a de minimis threshold to exist under Article 102 TFEU, and the ball is now in the General Court's court (quite literally) to further develop this notion.

\section{Rebates after Intel: The good, the bad and the ugly}

Three kinds of insights can be gained from the Intel case: one good, one bad, and one rather ugly. ${ }^{138}$ While the Intel Court gave some much-needed fresh legal guidance on how to assess rebates under EU competition law ("the good"), it also left several legal questions on the necessity to carry out economic tests such as the AEC test and their relationship with previ-

\footnotetext{
${ }^{135}$ Banasevic and Hellström, "When the chips are down", 301. On conflicting views within the Commission on this issue, see Venit, "The judgment of the European Court of Justice in Intel v. Commission", 196-197.

${ }^{136}$ Here, it is apt to recall Post Danmark II, where the Court clearly stated that the AEC test is but one possible analytical tool; Judgment of 6 October 2015, Post Danmark II, C23/14, EU:C:2015:651, paragraph 61.

${ }^{137}$ Judgment of 6 September 2017, Intel v. Commission, C-413/14 P, EU:C:2017:632, paragraph 139.

${ }^{138}$ It should be pointed out that Venit, in a recent contribution on Intel, used "The good and the bad" as a heading for his final remarks. This was only discovered by this author after submission of the title of her contribution to this journal. See Venit, "The judgment of the European Court of Justice in Intel v. Commission", 197.
} 
ous formalistic case law on rebates unanswered ("the bad"). As the case was referred back to the General Court, the Intel case remains unresolved - thus entailing continued legal uncertainty for other rebate cases ("the ugly"). These three insights are discussed in more depth in the following. Starting with the "good" in the Court's Intel judgment, a positive aspect of the judgment certainly is the fact that it finally gives some legal guidance on certain aspects of the antitrust assessment of rebates. As the Court itself stated, its intention was to clarify (or rather, re-interpret) its longstanding case law. The judgment offers a middle ground between the old formalistic case law and an entirely effects-based approach: While the legal presumption that a conditional rebate scheme is unlawful continues to stand, the Court has now shown how the company whose rebates are under scrutiny can rebut this presumption. In particular, the judgment shows that in cases where the Commission engages in laborious economics-based tests, those cannot be brushed aside as irrelevant at a later stage - neither by the General Court nor by the Commission itself. This also applies to the reliance on the AEC test in rebate cases. The competition assessment of rebates as outlined in the Commission's Guidance Paper has thereby started to get a hold in the case law. Intel was seen as a test case for the Commission's Guidance Paper approach to rebates from its outset, ${ }^{139}$ and this perhaps also helps to explain the amount of attention this case has received.

Moving on to the "bad" - or some more critical reflections on the judgment -, it should be pointed out that the judgment leaves several legal questions unanswered. While the Court's reasoning applies where the Commission actually engaged in economic benchmarking such as the AEC test, even if merely for the sake of completeness, it is less clear whether the Court's findings on the way to assess a rebate scheme's capability to restrict competition also apply more generally. Might the Court's reasoning only apply where the Commission actually engaged in such economic tests? The Court did not say that economic tests such as the AEC test constituted a necessary element of its legal test, and their relationship with the Court's previous formalistic case law on rebates, which had always focused on whether or not rebates induced or indeed were capable to induce loyalty among purchasers, ${ }^{140}$ remains at best ambivalent. While the General Court's Intel judgment was on occasion called "the end for

\footnotetext{
${ }^{139}$ Monti, “Article 82 EC”, 2.

${ }^{140}$ See also ibid., 9.
} 
the Commission's cost-based treatment of loyalty rebates", ${ }^{141}$ the Court's recent judgment does not altogether dismiss the AEC test as a valuable addition to the analysis of loyalty rebates. The question is, of course, which relationship will develop between the established case law and the AEC test. The Commission's argument that it merely undertook the AEC test for the sake of completeness did, in any case, not convince the Court.

In addition, the Court did not clarify which legal standard should apply to the capability to foreclose competition, which AG Wahl had given so much thought to. Another uncertainty relates to the three-part categorisation which the General Court had so clearly set out in its earlier Intel judgment, and which many commentators have read into the Court's Post Danmark II judgment. This categorisation had appeared to organise the complex law on rebates into an object and an effects category. While AG Wahl was openly critical of this categorisation, holding that there were only two categories at stake - volume-based rebates and loyalty rebates from all walks of life -, the Intel Court appeared to circumnavigate this question by first focusing on loyalty rebates in the Hoffmann-La Roche tradition and then adjusting the analytical framework so that it now in any case resembles the "all circumstances of the case" approach which the General Court had deemed necessary for third type rebates only.

A few remarks need to be made on the truly "ugly" side as well. As the Intel Court felt that it could not decide the case itself because the General Court had committed a serious error of law, the Intel case will be dragged on - possibly into its third decade. This also means that there is continued legal uncertainty for other rebate cases, as the question remains to which legal standard the European Commission has to prove the anti-competitive nature of a rebate scheme under Article 102 TFEU. Ongoing or potential cases cannot rely on a clear analytical framework for legally assessing rebate schemes under EU competition rules. It remains to be seen, of course, how the General Court will resolve the remanded case and how it will apply the Court's legal guidance.

\section{Final reflections}

Applying the AEC test that the Guidance Paper proposes in practice has been called "challenging", ${ }^{142}$ to say the least. Tomra and Intel are

\footnotetext{
${ }^{141}$ Ahmet F. Özkan, "The Intel judgment: the Commission threw the first stone but the EU courts will throw the last", European Competition Journal 11, no. 1 (2015): 84.

${ }^{142}$ Ezrachi, EU Competition Law, 247.
} 
perfect examples in point. The two cases have showcased how difficult it is to infuse the binding case law with more economics, and how such an attempt can ultimately lead to increased legal uncertainty for companies that want to grant rebates. While Intel was seen as an important milestone for the effects-based AEC test, it had been suggested in the literature that even if the Commission's AEC test were to be rejected by the European courts, the EU's competition watchdog "would suffer no set back as it was still applying, in parallel, the 'settled case law"'. ${ }^{143}$ In the light of the highly unexpected outcome of the Court's Intel judgment, one can now argue that it is because of the very fact that it carried out the AEC test that the Commission is now facing a potential defeat in this high-profile loyalty rebate case. In fact, it is somewhat ironic that there is a possibility that the Commission will ultimately lose its Intel case based on the AEC test which it added on to the established case law, but might have won it based on the Court's precedent alone. The latter assertion may be questioned based on the Court's hint that market coverage - and thus a sort of de minimis threshold - should be considered as a factor in the legal assessment: perhaps the Commission's Intel case was not as strong as it appeared to be at the outset, even without the addition of its economics-based analyses.

As a result of the Court's Intel judgment a number of options for analysing rebate schemes remain possible. Although it is quite unlikely, it would theoretically be possible for the Commission to purely base its next rebate case on the Court's formalistic case law. ${ }^{144}$ Would the Court accept such an approach, now that it has "clarified" its Hoffmann-La Roche case law in an effects-friendly way? The more challenging legal assessment, of course, would consist in consolidating the Court's formalistic case law with its now "clarified" effects-based approach, whereby the Commission (and in due course the General Court) need to respond to an incumbent's counter-arguments. Here, the question is whether legal presumptions - which often serve as short-cuts to swiftly reach the best outcome - will play any role in the future, or whether they are to be interpreted away in favour of an effects-based understanding.

Finally, it is worth re-considering the criticism that has been levied against the AEC test more generally. Such criticism includes the insight that loyalty rebates and predatory pricing do not relate to the same

\footnotetext{
${ }^{143}$ Nihoul, "The ruling of the General Court in Intel", 530.

${ }^{144}$ It has been cautioned that such a pick and choose approach would clearly go against equal treatment; see Monti, "Article 82 EC", 10. This is now also confirmed by the Intel Court.
} 
anti-competitive harm, the notion that competition is not only based on price alone, and the warning that the modest benefits of the AEC test do not justify the significant investment of resources it requires. Importantly, the AEC test is not in line with one of EU competition law's fundamental objectives: undistorted competition. ${ }^{145}$ The AEC test has been found to be a useful indicator of whether a rebate scheme makes market access impossible altogether - but it does not serve any purpose when trying to establish whether market access for competitors is simply made more difficult. ${ }^{146}$ As EU competition law also condemns rebates that achieve the latter, the AEC may not be the appropriate benchmark. In addition to that, the Intel case has shown that while both the Commission and Intel were prepared to invest considerable resources into the AEC test, they could not agree on the contestable share of the market, leading to contradictory results based on the same conceptual framework. This, it should be stressed, is a problem that many if not most economics-based tests face. It certainly does not serve the swift administrability of the competition law rules, nor their predictability. This is not to say that the conceptual framework of the AEC cannot improve our understanding of the ways in which rebate schemes foreclose competitors - in fact, the contrary is the case. As a legal benchmark for the assessment of loyalty rebates, however, it does not currently seem to fit the bill as a workable standard. The lingering question is: what does?

\section{Bibliography}

Banasevic, Nicholas and Per Hellström. "When the chips are down: Some reflections on the European Commission's Intel decision”. Journal of European Competition Law \& Practice 1, no. 4 (2010): 301-310.

Clarke, Julie. "The Opinion of AG Wahl in the Intel Rebates case: A triumph of substance over form?”. World Competition: Law \& Economics Review 40, no. 2 (2017): 241-269.

Ezrachi, Ariel. EU Competition Law: An Analytical Guide to the Leading Cases. $5^{\text {th }}$ ed. Oxford: Hart Publishing, 2016.

\footnotetext{
${ }^{145}$ Wils, "The judgment of the EU General Court in Intel", 428-431.

${ }^{146}$ Judgment of 12 June 2014, Intel v. Commission, T-286/09, EU:T:2014:547, paragraphs 88, 148149. The Guidance Paper also states that anti-competitive foreclosure encompasses situations where market access is "hampered or eliminated"; see European Commission, Guidance Paper, paragraph 19.
} 
Geradin, Damien. "Loyalty rebates after Intel: Time for the European Court of Justice to overrule Hoffman-La Roche". Journal of Competition Law and Economics 11, no. 3 (2015): 579-615.

Geradin, Damien. "The decision of the Commission of 13 May 2009 in the Intel case: Where is the foreclosure and consumer harm?". Journal of European Competition Law \& Practice 1, no. 2 (2010): 112-122.

Ibáñez Colomo, Pablo. "Comments on Case C-413/14 P, Intel: presumptions, effectsbased analysis and open questions”. Chillin'Competition Blog. 6 September 2017. https://chillingcompetition.com/2017/09/06/comments-on-intel-presumptionseffects-based-analysis-and-open-questions/.

Ibáñez Colomo, Pablo. "More on Intel: Some thoughts after the IBA Conference in Florence”. Chillin'Competition Blog. 12 September 2017. https://chillingcompetition. com/2017/09/12/more-on-intel-some-thoughts-after-the-iba-conference-in-florence/. Lundqvist, Björn. "Post Danmark II, now concluded by the ECJ: Clarification of the rebate abuse, but how do we marry Post Danmark I with Post Danmark II?". European Competition Journal 11, nos. 2-3 (2015): 557-573.

Marinova, Miroslava. "Should the rejection of the 'as efficient competitor' test in the Intel and Post Danmark II judgements lead to dismissal of the effect-based approach?”. European Competition Journal 12, nos. 2-3 (2016): 387-408.

Mazzone, Luca and Alberto Mingardi. "Innovation, competition and antitrust: An examination of the Intel Case”. Economic Affairs 31, no. 2 (2011): 68-75.

Monti, Giorgio. “Article 82 EC: What future for the effects-based approach?”. Journal of European Competition Law \& Practice 1, no. 1 (2010): 2-11.

Nihoul, Paul. "The ruling of the General Court in Intel: Towards the end of an effectbased approach in European Competition Law?”. Journal of European Competition Law \& Practice 5, no. 8 (2014): 521-530.

Oliveira Pais, Sofia. "Os descontos de exclusividade numa encruzilhada". In Estudos em Homenagem ao Conselheiro Presidente Rui Moura Ramos, 1219-1238. Lisbon: Almedina, 2016, vol I.

Özkan, Ahmet Fatih. "The Intel judgment: the Commission threw the first stone but the EU courts will throw the last". European Competition Journal 11, no. 1 (2015): 69-85.

Petit, Nicolas. "Intel, leveraging rebates and the goals of Article 102 TFEU." European Competition Journal 11, no. 1 (2015): 26-68.

Rey, Patrick and James S. Venit. "An effects-based approach to Article 102: A response to Wouter Wils". World Competition: Law \& Economics Review 38, no. 1 (2015): 3-29. 
Sher, Brian. "Keep calm - yes; carry on - no! A response to Whish on Intel". Journal of European Competition Law \& Practice 6, no. 4 (2015): 219-220.

Venit, James S. "Case T-286/09 Intel v. Commission - The judgment of the General Court: All steps backward and no steps forward". European Competition Journal 10, no. 2 (2014): 203-230.

Venit, James S. "The judgment of the European Court of Justice in Intel - Commission: A procedural answer to a substantive question?”. European Competition Journal 13, nos. 2-3 (2017): 172-198.

Whish, Richard. “Intel v. Commission: Keep calm and carry on!”. Journal of European Competition Law \& Practice 6, no. 1 (2014): 1-2.

Whish, Richard and David Bailey. Competition Law. $8^{\text {th }}$ ed. Oxford: Oxford University Press, 2015.

Wils, Wouter P. J. “The judgment of the EU General Court in Intel and the so-called more economic approach to abuse of dominance". World Competition: Law \& Economics Review 37, no. 4 (2014): 405-434. 